\title{
Penerapan Project Based Learning Menggunakan Microblogging Edmodo untuk Meningkatkan Prestasi Belajar Siswa Pada Pembelajaran Matematika
}

\author{
Saepulloh $^{1}$, Fitri Nurhayati², Iwan Darmawan ${ }^{3}$ \\ abi03nazwa@gmail.com, fitrinuhayati190@gmail.com
}

\begin{abstract}
The purpose of this study was to determine the effectiveness of using a project-based learning model using Edmodo microblogging in improving student achievement in mathematics learning. This study uses a quantitative approach with a quasi-experimental method. The results showed that the increase in student achievement by using project-based learning using Edmodo in the experimental class was higher than the conventional method in the control class. Student responses amounted to $87.23 \%$. shows that students give a very good/positive response to project-based learning using Edmodo microblogging.
\end{abstract}

Keywords: Edmodo;Project-Based Learning;Student Learning Achievement

\begin{abstract}
Abstrak
Tujuan penelitian ini adalah untuk mengetahui efektivitas penggunaan model pembelajaran project based learning dengan menggunakan microblogging edmudo dalam meningkatkan prestasi belajar siswa pada pembelajaran matematika. Penelitian ini menggunakan pendekatan kuantitatif dengan metode kuasi eksperimen. Hasil penelitian menunjukan peningkatan prestasi belajar siswa dengan menggunakan project based learning menggunakan edmudo pada kelas eksperimen lebih tinggi dibandingkan dengan metode konvensional pada kelas control. Tanggapan siswa sebesar 87.23\%. menunjukan bahwa siswa memberikan respon yang sangat baik/positif terhadap project based learning menggunakan microblogging edmudo.
\end{abstract}

Kata Kunci: Edmudo;Prestasi Belajar Siswa;Project Based Learning

\section{PENDAHULUAN}

Pemerintah melalui UU No 20 Tahun 2003 mengamanatkan bahwa pendidikan merupakan usaha sadar dan terencana untuk mewujudkan suasana belajar dan proses pembelajaran agar peserta didik secara aktif mengembangkan potensi dirinya untuk memiliki kekuatan spiritual keagamaan, pengendalian diri, kepribadian, kecerdasan, akhlak mulia, serta keterampilan yang diperlukan dirinya, masyarakat, bangsa dan negara. Peran pendidikan diharapkan mampu melahirkan sumber daya manusia yang berkualitas yang memiliki keunggulan kompetitif dalam kehidupan global dan memiliki pondasi iman dan takwa kepada Tuhan Yang Maha Esa.

Penyelenggaraan pendidikan diwujudkan melalui pembelajaran yang merupakan proses untuk membantu peserta didik dalam melakukan aktivitas belajarnya guna mewujudkan perubahan perilaku kearah yang lebih baik. Perubahan perilaku yang dimaksud mencakup perubahan kemampuan kognitif, afektif, dan psikomotorik yang berguna bagi dirinya untuk menghadapi perkembangan zaman.

Dalam rangka menghasilkan sumber daya manusia yang berkualitas menempatkan bidang pendidikan dan pembelajaran memiliki peran dan fungsi yang strategis menuntut tenaga pendidik 
menyelenggarakan pembelajaran yang inovatif, efektif, dan efisien. Maka dari itu, seorang tenaga pendidik harus bisa merancang dan melaksanakan pembelajaran sesuai dengan kebutuhan dan kondisi dilapangan dengan memanfaatkan sumber daya yang tersedia. Penerapan metode dan media pembelajaran yang efektif dirasa dapat membantu aktivitas belajar peserta didik dan guru dalam menyampaikan materi pelajaran. Seiiring dengan perkembangan teknologi informasi sudah seharusnya tenaga pendidik perlu menerapkan pembelajaran berbasis ICT. Microblogging memiliki potensi besar untuk dapat dimanfaatkan dalam pembelajaran, salah satu situs microblogging yang dapat dimanfaatkan sebagai sumber belajar dan alat pembelajaran adalah Edmodo. Project based learning merupakan model pembelajaran yang memberikan kesempatan kepada siswa untuk merencanakan aktivitas belajar secara mandiri dalam kegiatan kerja proyek (Sumarmi, 2012)[1] sehingga dapat memfasilitasi aktivitas belajar siswa sesuai dengan gaya belajarnya.

Penggunaan project based learning menggunakan microblogging edmudo diharapkan dapat membantu aktivitas guru dalam mengajar dan memberikan kesempatan belajar mandiri kepada peserta didik untuk mewujudkan tujuan pembelajarannya. Amar Mahfudin (2013)[2] bahwa penggunaan media edmodo sebagai kegiatan penunjang pembelajaran sangat efektif digunakan pada proses pembelajaran Dasar Kompetensi Kejuruan dilihat dari respon dan hasil belajar pesrta didik. Tujuan penilitian ini adalah untuk mengetahui efektivitas penggunaan model pembelajaran project based learning dengan menggunakan microblogging edmudo dalam meningkatkan prestasi belajar siswa pada pembelajaran matematika.

Berdasarkan pemaparan latar belakang, maka rumusan masalah dalam penelitian ini adalah :

1. Apakah penerapan project based learning menggunakan microblogging Edmodo memiliki efektifitas yang lebih tinggi daripada pembelajaran konvensional dalam meningkatkan prestasi belajar siswa pada pembelajaran matematika?

2. Bagaimana tanggapan siswa terhadap pembelajaran Project based learning menggunakan microblogging edmodo?

\section{KAJIAN TEORITIS}

\section{Media Pembelajaran}

Media pembelajaran merupakan seperangkat alat bantu atau pelengkap yang digunakan oleh guru atau pendidik berinteraksi dengan peserta didik dalam pelaksanaan pembelajaran. Gagne Briggs (dalam Arsyad, 2002)[3], berpendapat bahwa media pemb" elajaran adalah sesuatu alat yang secara fisik digunakan untuk menyampaikan isi materi pembelajaran. Media pembelajaran tersebut dapat berupa buku, tape recorder, kaset video, film, slide, foto, gambar, televise, dan komputer. Sadiman (2002)[4], mengemukakan bahwa media pembelajaran adalah bermacam peralatan digunakan guru untuk menyampaikan pesan kepada siswa melalui penglihatan dan pendengaran. Berdasarkan pendapat ahli tersebut, dapat disimpulkan bahwa media pembelajaran merupakan alat yang digunakan oleh guru dalam menyampaikan pesan atau informasi kepada peserta didik dapat berupa buku, tape recorder, kaset video, film, slide, foto, gambar, televise, dan komputer. 
Dalam pembelajaran, seorang guru hendaknya dapat menggunakan media pembelajaran yang tepat sesuai dengan karateristik dan gaya belajar siswa. Hal ini menjadi dasar bagi guru dalam menentukan media pembelajaran untuk digunakan dalam pelaksanaan pembelajaran. Brown (1983:17)[5] menyatakan bahwa "educational media of all types incresaingly important roles in enabling students to reap benefits from individualized learning", semua jenis media pembelajaran akan terus meningkatkan peran untuk memungkinkan siswa memperoleh manfaat dari pembelajaran yang berbeda. Menggunakan media pembelajarn secara efektif, akan menciptakan suatu proses belajar mengajar yang optimal. Pernyataan tersebut dapat disimpulkan bahwa media pembelajaran merupakan salah satu bagian penting dari proses pembelajaran.

Media pembelajaran sangat bermanfaat bagi dunia pendidikan. Berdasarkan beberapa pendapat ahli diatas dapat disimpulkan bahwa manfaat media pembelajaran dalam dunia pendidikan adalah (1) media pembelajaran dapat memperjelas pesan pembelajaran yang disampaikan oleh guru kepada siswa, (2) media pembelajaran bermanfaat untuk membantu guru dalam mengatasi masalah dalam proses belajar mengajar, (3) manfaat media pembelajaran adalah membantu guru dalam meningkatkan stimulus kepada siswa sehingga respon siswa terhadap pelajaran menjadi baik (Sudjana, 2007).[6]

\section{Project Based Learning}

Project Based Learning atau PBL adalah penugasan proyek dalam proses belajar dengan tujuan memperdalam materi pelajaran dengan menempatkan siswa untuk mengungkapkan pertanyaan-pertanyaan investigatif dan juga teknologi yang relevan dengan hidup mereka. Proyekproyek ini juga berfungsi sebagai bahan menguji dan menilai kompetensi siswa pada mata pelajaran tertentu, bukan dengan menggunakan ujian tertulis konvensional (Kreshna:2012)[7]. Pembelajaran Berbasis Proyek (Project Based Learning) adalah model pembelajaran yang menggunakan proyek/kegiatan sebagai inti pembelajaran. Peserta didik melakukan eksplorasi, penilaian, interpretasi, sintesis, dan informasi untuk menghasilkan berbagai bentuk hasil belajar.

$\begin{array}{ccr}\text { Pelaksanaan } & \text { pembelajaran } \\ \text { project } & \text { bertujuan agar siswa }\end{array}$ mengembangkan pemikiran mandiri siswa dan rekan kelompok dengan menginvestigasi materi pelajaran diharapkan siswa secara otomatis akan mengembangkan pula kemampuan riset mereka. Siswa secara aktif terlibat dalam proses pendefinisian masalah, pemecahan masalah, pengambilan keputusan, dan aktivitas investigatif lainnya ( Darmawan,2018)[8]. Mereka didorong untuk memunculkan ide-ide serta solusi realistis. Pendekatan PBL ini menciptakan lingkungan belajar di mana siswa "membangun" pengetahuan mereka sendiri. Guru di PBL benarbenar lebih berfungsi sebagai fasilitator. Dalam pembelajaran ini benar-benar diutamakan antusiasme dan keterlibatan para siswa dalam proses belajar mengajar.

Project Based Learning ini berbeda dengan pembelajaran langsung yang menekankan pada prestasiide-ide dan keterampilan pendidik. Peran pendidik pada metode Project Based Learning adalah menyajikan masalah, mengajukan pertanyaan dan memfasilitasi penyelidikan dan dialog. Pembelajaran dengan metode Project Based Learning harus menggunakan 
masalah masalah nyata sehingga peserta pelatihan belajar, berpikir, kritis dan terampil memecahkan masalah dan mendukungpengembangan keterampilan teknis serta perolehan pengetahuan yang mendalam. Pada metode pembelajaran Project Based Learning ini memfokuskan pada: pemecahan masalah nyata, kerja kelompok, umpan balik, diskusi dan laporan akhir. Peserta didik didorong untuk lebih aktif terlibat dalam materi pelajaran dan mengembangkan keterampilan berpikir kritis, sehingga peserta didik berlatih melakukan penyelidikan dan inkuiri (Levin, 2001)[9].

\section{Microblooging Edmudo}

Edmodo adalah platform pembelajaran yang aman bagi guru, siswa dan sekolah berbasis sosial media. Edmodo menyediakan cara yang aman dan mudah bagi kelas untuk terhubung dan berkolaborasi antara siswa dan guru untuk berbagi konten pendidikan, mengelola proyek dan tugas dan menangani pemberitahuan setiap aktivitas. Edmodo dapat membantu pengajar membangun sebuah kelas virtual sesuai dengan kondisi pembelajaran di dalam kelas, berdasarkan pembagian kelas nyata di sekolah, dimana dalam kelas tersebut terdapat penugasan, quiz dan pemberian nilai pada setiap akhir pembelajaran.

Keunggulan Edmodo, antara lain menyediakan fasilitas yang mudah dan aman dalam mengembangkan kelas sesuai dengan keinginan, memberi kesempatan terjadinya pembelajaran sesuai karakteristik murid yang berbeda secara personal, dan menyediakan sarana komunikasi bagi guru,siswa dan orang tua/wali murid secara personal. Keunggulan lainnya adalah Edmodoakan memudahkan guru, siswa dan orang tua dalam berbagai ide /gagasan, berbagi file, penugasan PR, penilaian, kuis/ulangan, polling, diskusi, mengingatkan tugas dll. Keunggulan lain dari edmodo saat dimana guru tidak dapat bertatap muka dengan siswa di karenakan guru berhalangan hadirdengan adanya edmodo guru dapat memberikan tugas kepada siswa secara online dan tujuan pembelajaran akan tercapai sesuai dengan target pembelajaran tersebut.

Fasilitas yang akan didapat seorang guru di Edmodo antara lain guru dapat mendesain kelas secara online sesuai keinginan, setiap kelas memiliki kode kelas yang unik(tiap kelas bisa dibuat berbeda), mengendalikan siapa saja yang boleh bergabung, berkomentar/ berpesan ke kelas, perorangan secara spesifik/individual, memberikan tugas, menanggapi dan menilai tugas yang telah dikerjakan, membuat kuis/ulangan interaktif, melakukan polling, membentuk kelompok-kelompok kecil, berkomunikasi secara personal, berkolaborasi dengan guru lainnya.

\section{Prestasi Belajar Siswa}

Prestasi adalah hasil yang telah dicapai dari yang telah dilakukan dan dikerjakan. Berkaitan dengan proses pembelajaran dan belajar, makana prestasi belajar siswa merupakan pencapaian yang dimliki oleh sisiwa setelah mengikuti pembelajaran dalam melakuka aktivitas belajar siswa. Dalam Kamus Besar Bahasa Indonesia disebutkan bahwa prestasi belajar adalah penguasaan pengetahuan atau ketrampilan yang dikembangkan melalui mata pelajaran, lazimnya ditunjukan dengan nilai tes atau angka yang diberikan oleh guru. Yang menjadi indikator bahwa suatu proses belajar mengajar dianggap berhasil adalah daya serap terhadap materi pelajaran yang diajarkan mencapai prestasi tinggi, baik secara individual maupun klasikal, dan perilaku yang ditentukan dalam tujuan pembelajaran telah dicapai oleh siswa 
Gunahumas

Jurnal Kehumasan

baik individual maupun klasikal (Syaiful

Bahri Djamarah dan Aswan Zain, 2002) [10].

Adapun faktor-faktor yang mempengaruhi prestasi belajar secara umum menurut (Slameto, 2008)[11] pada garis besarnya meliputi faktor intern seperti jasmanisah dan psikologis serta faktor ekstern seperti keluarga, sekolah, metode mengajar guru, masyarakat. Pengukuran prestasi belajar adalah sebuah proses berupa tindakan atau kegiatan untuk melihat sejauh mana tujuan-tujuan instruksional dapat dicapai oleh siswa dalam bentuk hasil belajar yang diperlihatkan setelah mereka menempuh proses belajar mengajar. Sama halnya dengan Sugihartono (2007)[12] mengungkapkan pengukuran prestasi belajar dimaksudkan untuk mengetahui seberapa jauh perubahan tingkah laku siswa setelah menghayati proses belajar. Sedangkan Djaali dan Pudji Muljono (2008: 2) [13], mengungkapkan bahwa pengukuran prestasi belajar yaitu suatu kegiatan yang dilakukan untuk mengukur dalam arti memberi angka terhadap sesuatu yang disebut obyek pengukuran atau obyek ukur.

METODE

Penelitian ini menggunakan pendekatan kuantitatif dengan metode kuasi eksperimen ( Darmawan,2019)[14]. Populasi dalam penelitian ini adalah siswa kelasVII dengan sampel sebanyak 50 siswa di SMPN 1 Leuwigoong Variabel bebas dalam penelitian ini adalah model pembelajaran project based learning menggunakan microblogging edmodo dan variabel terikat adalah prestasi belajar.

\section{HASIL DAN PEMBAHASAN}

Prestasi belajar siswa diukur dengan menggunakan instrument test hasil belajar dalam bentuk soal pilihan ganda yang diberikan kepada peserta didik yang berjumlah 25 orang pada kelas eksperien dan 25 siswa pada kelas kontrol. Perlakuan pembelajaran dengan menggunakan microblogging edmudo diberikan kepada kelas eksperimen dan metode konvensional diterapkan pada kelas control. Tujuan perbedaan perlakukan tersebut untuk membandingkan pencapaian efektifitas pada kedua kelompok dengan perlakuan yaitu penerapan project based learning menggunakan microblooging edmudo dan metode konvensional dalam meningkatkan prestasi belajar siswa. Sebelum perlakukan diterapkan, kedua kelompok terlebih dahulu diberikan pretest bertujuan untuk mengetahui pengetahuan awal peserta didik. Selanjutnya setelah treatment diterapkan, peneliti memberikan posttest untuk mengukur kemampuan akhir peserta didik mengenai prestasi belajar siswa. Berikut ini perbandingan hasil pretest dan posttest pada kedua kelompok ;

Tabel 1. Nilai Pretest dan Postest Kelompok Eksperimen dan Kontrol

\begin{tabular}{ccccc}
\hline & \multicolumn{2}{c}{ Kelas } & \multicolumn{2}{c}{ Kelas Kontrol } \\
& \multicolumn{2}{c}{ Eksperimen } & & \\
& Pretes & Postest & Pretes & Postest \\
\hline Rata & 20 & 85 & 25 & 70 \\
- & & & & \\
Rata & & & & \\
$\begin{array}{c}\text { Skor } \\
\text { Mak }\end{array}$ & 25 & 95 & 30 & 75 \\
$\quad$ s & & & & \\
$\begin{array}{c}\text { Skor } \\
\text { Min }\end{array}$ & 10 & 68 & 10 & 50 \\
\hline
\end{tabular}

Berdasarkan pada tabel 1 diperoleh data mengenai prestasi belajar siswa pada kelas eksperimen menunjukan nilai ratarata sebesar 85 lebih besar daripada kelas control sebesar 70 artinya penggunaan project based learning menggunakan edmudo lebih efektif dibandingkan 
metode konvensional dalam meningkatkan prestasi belajar peserta didik pada pembelajaran matematika.

Tabel 2. Perbandingan Peningkatan Prestasi

\begin{tabular}{lccc}
\multicolumn{4}{c}{ Belajar } \\
\hline Kelas & N & Mean & $\begin{array}{c}\text { Gain.T } \\
\text { ernm }\end{array}$ \\
\hline Eksperimen & 25 & 45.01 & 0.74 \\
Kontrol & 25 & 20.6 & 0.31
\end{tabular}

Berdasarkan tabel 2, peningkatan prestasi belajar siswa setelah dilakukan uji gain ternormalisasi diperoleh hasil gain ternormalisasi pada kelas eksperimen sebesar 0,74 dengan kategori tinggi dan kelas control dengan kategori sedang (Meltzer, 2002)[15] dan dapat disimpulkan bahwa peningkatan prestasi belajar siswa dengan menggunakan project based learning menggunakan edmudo pada kelas eksperimen lebih tinggi dibandingkan dengan metode konvensional pada kelas control.

Angket diberikan kepada siswa pada kelas eksperimen dengan tujuan untuk mengetahui sikap siswa terhadap penerapan project based learning menggunakan microblogging edmudo mata pelajaran matematika. Berikut ini hasil tanggapan siswa terhadap penerapan project based learning menggunakan microblogging edmudo mata pelajaran matematika.

Tabel 3. Tanggapan Siswa

\begin{tabular}{ccccc}
\hline Kelas & $\begin{array}{c}\text { Jumlah } \\
\text { Respon } \\
\text { den }\end{array}$ & $\begin{array}{c}\text { Sk } \\
\text { or } \\
\text { Tot } \\
\text { al }\end{array}$ & $\begin{array}{c}\text { Sk } \\
\text { or } \\
\text { ald }\end{array}$ & $\begin{array}{c}\text { Persent } \\
\text { ase }\end{array}$ \\
\hline $\begin{array}{c}\text { Eksperi } \\
\text { men }\end{array}$ & 25 & 19 & 22 & 87.23 \\
$\%$
\end{tabular}

Berdasarkan tabel 3 mengenai tanggapan siswa terhadap penerapan project based learning menggunakan microblogging edmudo mata pelajaran matematika sebesar $87.23 \%$. Hasil analisis angket secara umum menunjukkan bahwa kelompok siswa eksperimen menunjukkan respon yang sangat baik terhadap project based learning menggunakan microblogging edmudo.

Pelaksananaan pembelajaran akan efektif apabila guru dapat mengkombinasikan metode mengajar dengan media pembelajaran berbasis ICT terkait dengan penerapan project based learning menggunakan microblogging edmudo pada pembelajaran matematikan. Fungsi microblogging edmudo sebagai media pembelajaran dapat memperjelas penyajian pesan dan informasi sehingga dapat memperlancar dan meningkatkan proses dan hasil belajar. Peserta didik didorong untuk lebih aktif terlibat dalam materi pelajaran dan mengembangkan keterampilan berpikir kritis sehingga pelaksanaan pembelajaran berpusat pada peserta didik. Pentingnya student centered atau pembelajaran yang berpusat pada peserta didik dapat melatih kemampuan siswa untuk lebih mengeskplorasi dan mengaktualisasikan dirinya secara mandiri dalam aktivitas belajar dikelas. Implementasi project based learning, prinsip yang harus diikuti dalam implementasi project based learning menurut Thomas (2000)[16]: (a) sentralistis (centrality), (b) pertanyaan pendorong/penuntun (driving questions), (c) investigasi konstruktif (constructive investigation), (d) otonomy (autonomy), dan (e) realistis (realism). Project based learning (PBL) adalah sebuah model atau pendekatan pembelajaran yang inovatif, yang menekankan belajar kontekstual melalui kegiatan-kegiatan yang kompleks seperti memberi kebebasan pada siswa untuk bereksplorasi merencanakan aktivitas belajar, melaksanakan proyek secara kolaboratif, dan pada akhirnya menghasilkan suatu hasil produk (Rais, 2010)[17]. 
Media edmodo menyajikan konten materi yang bervariasi mencakup video, tekst, gambar, dan animasi sehingga dapat dapat melatih peserta didik berpikir aktif dan menarik perhatian siswa. Dalam media ini juga terdapat soal yang dapat melatih peserta didik memahami materi pembelajaran dengan menuliskan apa yang dia dengar, sehingga memudahkan peserta didik dalam memahami materi pembelajaran untuk mencapai hasil belajar yang optimal. Akses materi pelajaran dapat dilakukan tanpa terbatasnya ruang dan waktu sehingga aktivitas belajar dapat dilakukan dirumah maupun diluar kelas. Penggunaan media Edmodo direspon positif oleh peserta didik. Sebagai bentuk pengutan agar bisa memberikan dan memperhatikan efek yang positif maka perlu membiasakan peserta didik untuk selalu memanfaatkan perkembangan IPTEK, hal ini didukung dengan pembelajaran dengan internet, sehingga memudahkan peserta didik untuk dapat berdiskusi mengenai materi pembelajaran.

\section{DAFTAR PUSTAKA}

[1] Sumarmi, "Model-Model Pembelajaran," 2012.

[2] A. Mahfudin, "Efektivitas Penggunaan Media Edmudo Sebagai Kegiatan Penunjang Pembelajaran Dasae Kompetensi Kejuruan DI SMK Negeri 1 Majalengka," vol. 2013, no. August, pp. 27-33, 2013.

[3] A. Arsyad, "Media Pembelajaran." PT. Raja Grafindo Persada, jakarta, 2002.

[4] A. Sadiman, "Media Pembelajaran dan Proses Belajar Mengajar, Pengertian Pengembangan dan Pemanfaatannya." PT. Raja Grafindo Persada, Jakarta:, 2002.

[5] Y. Brown, "Discourse Analysis," 1983.

\section{SIMPULAN}

Efektivitas project based learning menggunakan microblogging edmudo dapat meningkatkan prestasi belajar siswa. Berdasarkan nilai rata-rata posttest dan uji gain ternormalisasi menunjukan nilai yang tinggi dibandingkan dengan kelas control yang menggunakan metode eksperimen. Artinya penggunaan project based learning menggunakan edmudo lebih efektif dibandingkan metode konvensional dalam meningkatkan prestasi belajar peserta didik pada pembelajaran matematika.

Hasil analisis angket menunjukkan microblogging edmudo mata pelajaran matematika sebesar $87.23 \%$. menunjukan bahwa kelompok siswa memberikan respon yang sangat baik/positif terhadap project based learning menggunakan microblogging edmudo.

[6] N. dan R. Sudjana, "Media Pengajaran. Bandung:," Bandung Sinar Baru Algesindo., 2011.

[7] Kresna, "NPengertian dan langkah-langkah Model Pembelajaran Project Base Learning (Pembelajaran Berbasis Proyek)," 2012.

[8] D. Darmawan and D. Wahyudin, Model Pembelajaran Di Sekolah. Bandung, 2018.

[9] B. (Ed. ). Levin, "Energizing Teacher Education And Professional Development With Problem-Based Learning. Alexandria, VA:

Association for Supervision and Curriculum Development," 2001.

[10] S. B. D. dan A. Zain, "Strategi Belajar Mengajar," 2002.

[11] Slameto., "Faktor-Faktor yang Mempengaruhi Belajar," 2008.

[12] D. Sugihartono, "Psikologi 
Pendidikan," 2007.

[13] D. \& P. Muljono, "Pengukuran

Dalam Bidang Pendidikan.” PT.

Grasindo., Jakarta:, 2008.

[14] D. Darmawan, Metode Penelitian

Kuantitatif, Ke empat. Bandung,

2019.

[15] D. . Meltzer, "Pretest Scores," 2002.

[16] Thomas, "Pengembangan Model

Pembelajaran Project Based

Learning," 2000.

[17] M. Rais, "roject Based Learning: Inovasi Pembelajaran yang

Berorientasi Soft Skills. Makalah

disajikan Sebagai makalah

Pendamping dalam Seminar Nasional

Pendamping dalam Seminar Nasional

Pendidikan Teknologi dan Kejuruan

Fakultas Teknik Universitas Negeri

Surabaya," 2010. 